\title{
Editorial \\ Challenging the Status Quo to Shape Food Systems Transformation from a Nutritional and Food Security Perspective
}

\author{
António Raposo $^{1, *(\mathbb{D})}$, Renata Puppin Zandonadi ${ }^{2}$ (D) and Raquel Braz Assunção Botelho ${ }^{2}$ (D) \\ 1 CBIOS (Research Center for Biosciences and Health Technologies), Universidade Lusófona de Humanidades e \\ Tecnologias, Campo Grande 376, 1749-024 Lisboa, Portugal \\ 2 Department of Nutrition, Faculty of Health Sciences, University of Brasilia, Brasilia 70910-900, Brazil; \\ renatapz@unb.br (R.P.Z.); raquelbotelho@unb.br (R.B.A.B.) \\ * Correspondence: antonio.raposo@ulusofona.pt
}

check for updates

Citation: Raposo, A.; Zandonadi, R.P.; Botelho, R.B.A. Challenging the Status Quo to Shape Food Systems Transformation from a Nutritional and Food Security Perspective. Foods 2022, 11, 604. https://doi.org/ $10.3390 /$ foods 11040604

Received: 16 February 2022 Accepted: 17 February 2022 Published: 20 February 2022

Publisher's Note: MDPI stays neutral with regard to jurisdictional claims in published maps and institutional affiliations.

Copyright: (C) 2022 by the authors. Licensee MDPI, Basel, Switzerland. This article is an open access article distributed under the terms and conditions of the Creative Commons Attribution (CC BY) license (https:// creativecommons.org/licenses/by/ $4.0 /)$.
Keywords: consumer; environment; food policy; food production; food safety; food security; nutrition; sustainability

Food security and nutrition have been prominent elements of the international development agenda. Over time, however, development priorities and challenges have oscillated, and the investment required has not been sustained. A broader consensus has emerged: one that guarantees food security and, in all its aspects, reduces hunger and malnutrition to promote strong economies, human and planetary health, and sustainable development. Our moral imperative is to positively change food systems to ensure that the food we produce is accessible, sustainable, safe, healthy, and equitable for everyone. Therefore, this special issue about Food Systems and Nutritional and Food Security focuses on connecting the importance of food systems to change nutrition and food security around the globe.

In this context, attitude and knowledge of health, food, and nutrition can be one of the keys to facing food insecurity in several countries. Health and nutritional education are imperative to fight malnutrition [1-4]. Knowledge in these aspects is essential in tackling misinformation and promoting good food choices. Since birth, it can be constructed along life using households, schools, the internet, and other channels to allow learning on food, health, and nutrition and stimulate adequate food choices [1-7].

Adequate and healthy diets imply choosing and consuming balanced and adequate foods on nutrients and amount, variety, and sustainable aspects. Therefore, achieving the main social, economic, environmental, cultural, and security goals [1,3,6-16]. Food production must also be alert to the waste produced in the food chain related to environmental pollution and food waste that could be used to feed food-insecure people $[10,15,17]$. In order to support sustainable and healthy diets and food security, it is also essential to search for alternatives to stimulate local production and regional food consumption. Other priorities are reducing animal suffering and meat consumption, food production in sufficient quantity and quality with the least possible waste production, and understanding the main aspects of food, nutrition, society, and the environment [11-22].

During these past two years of the COVID-19 pandemic, the world has faced new food security and safety challenges. Firstly, food sales worldwide became more complex, and farmers faced many overstocked products leading to food loss [8]. On the other hand, countries' economic crisis conducted to more unemployment, therefore, more food insecurity. Governments need to learn from this period and improve the food supply chain with innovative techniques and logistics to have more organized food systems [8]. To guarantee the four pillars of food security, availability, access, stability, and utilization, Sun and Zhang [9] emphasize the importance of trade openness and sustainable food system strategies. Guiné et al. [7] discuss that the agrifood supply chain should be improved 
through policies worldwide to promote access to healthy and sustainable food. Authors also call the attention to researchers to rethink the four pillars of food security to include new dimensions like climate change.

Author Contributions: Conceptualization, A.R., R.P.Z. and R.B.A.B.; methodology, A.R., R.P.Z. and R.B.A.B.; resources, A.R., R.P.Z. and R.B.A.B.; data curation, A.R., R.P.Z. and R.B.A.B.; writingoriginal draft preparation, R.P.Z. and R.B.A.B.; writing-review and editing, A.R., R.P.Z. and R.B.A.B.; visualization, A.R., R.P.Z. and R.B.A.B. All authors have read and agreed to the published version of the manuscript.

Funding: This research received no external funding.

Institutional Review Board Statement: Not applicable.

Informed Consent Statement: Not applicable.

Acknowledgments: We would like to thank and congratulate all the authors who published their manuscripts to this special issue with FOODS/MDPI for this valuable data collection. We also thank the reviewers, the FOODS Editor-in-chief, and the entire MDPI team, without which it would be impossible to construct this successful special issue. We also thank the Brazilian National Council for Scientific and Technological Development (CNPq) for the Support.

Conflicts of Interest: The authors declare no conflict of interest.

\section{References}

1. Shapu, R.C.; Ismail, S.; Lim, P.Y.; Ahmad, N.; Garba, H.; Njodi, I.A. Effectiveness of Triple Benefit Health Education Intervention on Knowledge, Attitude and Food Security towards Malnutrition among Adolescent Girls in Borno State, Nigeria. Foods 2022, 11, 130. [CrossRef] [PubMed]

2. Florença, S.G.; Ferreira, M.; Lacerda, I.; Maia, A. Food Myths or Food Facts? Study about Perceptions and Knowledge in a Portuguese Sample. Foods 2021, 10, 2746. [CrossRef] [PubMed]

3. dos Santos, E.B.; Maynard, D.D.C.; Zandonadi, R.P.; Raposo, A.; Botelho, R.B.A. Sustainability Recommendations and Practices in School Feeding: A Systematic Review. Foods 2022, 11, 176. [CrossRef] [PubMed]

4. de Queiroz, F.L.N.; Nakano, E.Y.; Botelho, R.B.A.; Ginani, V.C.; Raposo, A.; Zandonadi, R.P. Eating Competence among Brazilian Adults: A Comparison between before and during the COVID-19 Pandemic. Foods 2021, 10, 2001. [CrossRef] [PubMed]

5. Cupertino, A.; Maynard, D.; Queiroz, F.; Zandonadi, R.; Ginani, V.; Raposo, A.; Saraiva, A.; Botelho, R. How Are School Menus Evaluated in Different Countries? A Systematic Review. Foods 2021, 10, 374. [CrossRef] [PubMed]

6. Lu, Y.; Zhang, Y.; Hong, Y.; He, L.; Chen, Y. Experiences and Lessons from Agri-Food System Transformation for Sustainable Food Security: A Review of China's Practices. Foods 2022, 11, 137. [CrossRef]

7. Guiné, R.D.P.F.; de Jesus Pato, M.L.; da Costa, C.A.; Costa, D.D.V.T.A.D.; da Silva, P.B.C.; Martinho, V.J.P.D. Food Security and Sustainability: Discussing the Four Pillars to Encompass Other Dimensions. Foods 2021, 10, 2732. [CrossRef]

8. Pu, M.; Chen, X.; Zhong, Y. Overstocked Agricultural Produce and Emergency Supply System in the COVID-19 Pandemic: Responses from China. Foods 2021, 10, 3027. [CrossRef]

9. Sun, Z.; Zhang, D. Impact of Trade Openness on Food Security: Evidence from Panel Data for Central Asian Countries. Foods 2021, 10, 3012. [CrossRef]

10. Rao, M.; Bilić, L.; Duwel, J.; Herentrey, C.; Lehtinen, E.; Lee, M.; Calixto, M.A.D.; Bast, A.; de Boer, A. Let Them Eat Fish!Exploring the Possibility of Utilising Unwanted Catch in Food Bank Parcels in The Netherlands. Foods 2021, 10, 2775. [CrossRef]

11. Chaosap, C.; Sahatsanon, K.; Sitthigripong, R.; Sawanon, S.; Setakul, J. The Effects of Using Pineapple Stem Starch as an Alternative Starch Source and Ageing Period on Meat Quality, Texture Profile, Ribonucleotide Content, and Fatty Acid Composition of Longissimus Thoracis of Fattening Dairy Steers. Foods 2021, 10, 2319. [CrossRef] [PubMed]

12. Uyeh, D.D.; Asem-Hiablie, S.; Park, T.; Kim, K.; Mikhaylov, A.; Woo, S.; Ha, Y. Could Japonica Rice Be an Alternative Variety for Increased Global Food Security and Climate Change Mitigation? Foods 2021, 10, 1869. [CrossRef] [PubMed]

13. Soares, P.; Martinelli, S.; Davó-Blanes, M.; Fabri, R.; Clemente-Gómez, V.; Cavalli, S. Government Policy for the Procurement of Food from Local Family Farming in Brazilian Public Institutions. Foods 2021, 10, 1604. [CrossRef] [PubMed]

14. Njoga, U.; Njoga, E.; Nwobi, O.; Abonyi, F.; Edeh, H.; Ajibo, F.; Azor, N.; Bello, A.; Upadhyay, A.; Okpala, C.; et al. Slaughter Conditions and Slaughtering of Pregnant Cows in Southeast Nigeria: Implications to Meat Quality, Food Safety and Security. Foods 2021, 10, 1298. [CrossRef]

15. Althumiri, N.A.; Basyouni, M.H.; Duhaim, A.F.; AlMousa, N.; AlJuwaysim, M.F.; BinDhim, N.F. Understanding Food Waste, Food Insecurity, and the Gap between the Two: A Nationwide Cross-Sectional Study in Saudi Arabia. Foods 2021, 10, 681. [CrossRef]

16. Bvenura, C.; Witbooi, H.; Kambizi, L. Pigmented Potatoes: A Potential Panacea for Food and Nutrition Security and Health? Foods 2022, 11, 175. [CrossRef] 
17. Poto, M.P.; Elvevoll, E.O.; Sundset, M.A.; Eilertsen, K.-E.; Morel, M.; Jensen, I.-J. Suggestions for a Systematic Regulatory Approach to Ocean Plastics. Foods 2021, 10, 2197. [CrossRef]

18. Anastasiadis, F.; Apostolidou, I.; Michailidis, A. Food Traceability: A Consumer-Centric Supply Chain Approach on Sustainable Tomato. Foods 2021, 10, 543. [CrossRef]

19. Rahman, M.; Islam, R.; Hasan, S.; Zzaman, W.; Rana, R.; Ahmed, S.; Roy, M.; Sayem, A.; Matin, A.; Raposo, A.; et al. A Comprehensive Review on Bio-Preservation of Bread: An Approach to Adopt Wholesome Strategies. Foods 2022, 11, 319. [CrossRef]

20. Suhandoko, A.A.; Chen, D.C.-B.; Yang, S.-H. Meat Traceability: Traditional Market Shoppers' Preferences and Willingness-to-Pay for Additional Information in Taiwan. Foods 2021, 10, 1819. [CrossRef]

21. Iftekhar, A.; Cui, X.; Yang, Y. Blockchain Technology for Trustworthy Operations in the Management of Strategic Grain Reserves. Foods 2021, 10, 2323. [CrossRef]

22. Chen, L.; Cui, X.; Li, W. Meta-Learning for Few-Shot Plant Disease Detection. Foods 2021, 10, 2441. [CrossRef] 